\title{
THE LEGAL PROTECTION OF DOMESTIC WORKERS IN SOUTH AFRICA: A SQUARE PEG IT IS (INTO A ROUND HOLE)
}

\author{
Lux Lesley Kubjana \\ LLB LLM \\ Lecturer, Mercantile Law \\ University of South Africa, Pretoria (UNISA)
}

\section{SUMMARY}

In an ideal world working as domestic worker would arguably be nobody's choice, but as things stand the socio-economic realities we find ourselves under dictates. There are fewer number of job opportunities than there are people looking for opportunities. According to statistics South Africa, the unemployment rate in South Africa is a shocking $25.4 \%$. Out of desperation and the need to survive most unemployed people have sought solace in the domestic sector. Little do they know that, what seems to be a breakthrough may actually turn out to be quite worse than they reckoned. It is no secret that most domestic workers do not know their job scope, a problem which can be attributed to quite a number of factors, for example, an inherent illiteracy level, desperation after an unsuccessfully long search for competitive opportunities, or unscrupulous employers who exploit them, often with impunity. In line with this, Grossman ${ }^{2}$ concluded that pay and working conditions of domestic workers depend on the employer's "goodwill", as employers are not impeded by labour legislation in their actions. ${ }^{3}$ The purpose of this article is to show and stress the point that the general labour law framework and the interventions made in South Africa to date do not empower domestic workers as long as they fail to take cognizance of occupational uniqueness of this sector. The author will define "domestic worker" and then proceed with the comparison of the existing legislative framework in South Africa with the best international standards in as far as they provide for domestic workers, and the extent thereof, while also arguing that infusing value dosages into law, such as ubuntu, may restore the lost dignity of the domestic worker in South Africa.

\section{INTRODUCTION}

It is no secret that domestic sector has been and continues to be a source of employment to a sizeable number of people worldwide, generally women,

http://beta2.statssa.gov.za/.

2 Grossman J "Summary of Submission on BCEA Bill" http://www.polity.org.za/govdocs/ parliament/submissions/basucgross.html (1997); and see also King Domestic Service in Post-apartheid South Africa: Deference \& Disdain (2007).

3 90. See also Whisson and Weil Domestic Servants: A Microcosm of the Race Problem (1978) 44 
but also men. ${ }^{4}$ This is arguably due to a limited number of job opportunities or socio-economic demands. Studies have shown that over a million and half of the workforce in South Africa is made up of domestic workers, ${ }^{5}$ and of this number only 652676 are registered as required by the law, ${ }^{6}$ but enough has not been done in terms of causing the employers to register, or to advise domestic workers on the importance of registration, associated benefits and also making the registration facilities more accessible to the consumers.

Domestic workers are doubtlessly providing most essential services to many households. They are simply just not dispensable. Not only do they provide a livelihood for themselves and their families, but also enable their employers to better their standard of living by maintaining employment outside their home. ${ }^{7}$ A similar view is held by Ally. ${ }^{8}$ The latter notes that, while domestic workers do the "dirty work" of cleaning their employers' toilets, or entertaining their employers' children, they free them (employers) to engage in accumulating other forms of capital ... and creating the wealth of the country ${ }^{9} \ldots$, while limiting domestic workers' abilities to engage in these "value-added" activities themselves. ${ }^{10}$ May ${ }^{11}$ observes that doing without household workers is just not possible. ${ }^{12}$ This explains the growing market for domestic workers in South Africa, along with anywhere else.

4 Figures by the ILO estimated that there are at least 53 million domestic workers worldwide, not including child-domestic workers, and this number is increasing steadily in developed and developing countries http://www.labour.gov.za/DOL/media-desk/media-statements/ 2014/domestic-workers-must-register-for-uif-2013-labour-minister. It is, however, believed that this number may well be an underestimation. This may well be qualified by the fact that most domestic workers are not registered: thus making it relatively difficult to trace them and include in the surveys processes. A report compiled by ILO indicates that domestic workers in urban areas too, make use of domestic workers - An Overview of Domestic Work in Africa - Making Decent Work a Reality for Domestic Worker in Africa: A Regional Knowledge Sharing Forum Dar es Salaam, Tanzania 28-30 May 2013 http://www.ilo.org/ wcmsp5/groups/public/africa/documents/meetingdocument/wcms 213683.pdf 1. See also Domestic Workers Count too: Implementing Protections for Domestic Workers http://www.unwomen.org/ /media/Headquarters/Attachments/Sections/Library/Publications/ 2013/3/UNWomen IUTC Factsheets\%20pdf.pdf.

5 http://www.southafrica.info/services/rights/domesticrights.htm. See also Blofield Care Work and Class: Domestic Workers' Struggle for Equal Rights in Latin America (2012) 32.

6 Unemployment Insurance Act 63 of 2001 and Unemployment Insurance Contribution Act 4 of 2003. Domestic workers have been included since 1 April $2003 \mathrm{http}: / /$ www.labour.gov.za/ DOL/legislation/acts/basic-guides/basic-guide-to-uif-registration.

7 Research conducted by Human Rights Watch entitled the Domestic Workers Convention: Turning New Global Labor Standards Into Change On The Ground http://www.hrw.org/sites/ default/files/related_material/The\%20Domestic\%20Workers\%20Convention\%20\%20Turnin g\%20New\%20Global\%20Labor\%20Standards\%20into\%20Change\%20on\%20the\%20Grou nd_0.pdf.

8 Ally From Servants to Workers: South African Domestic Workers and the Democratic State (2009).

9 SADSAWU submission to Portfolio Committee on Labour, the Parliament of South Africa $2^{\text {nd }}$ August $2011 \mathrm{http}: / /$ www.Irs.org.za/docs/201108\%20Sadsawu\%20submission\%20to\%20Par liamentary\%20Portfolio\%20Committee\%200n\%20Labour.pdf.

10 5. See also SADSAWU submission to Portfolio Committee on Labour, the Parliament of South Africa $2^{\text {nd }}$ August 2011 http://www.Irs.org.za/docs/201108\%20Sadsawu\%20sub mission\%20to\%20Parliamentary\%20Portfolio\%20Committee\%20on\%20Labour.pdf.

11 Unprotected Labour: Household Workers, Politics and Middle-class Reform in New York 1870-1940 (2011).

1221. 
Notwithstanding the essential services they provide, domestic workers are generally treated as failures in life $;^{13}$ their occupation is seen as the lowest in terms of status in the employment hierarchy, ${ }^{14}$ and remains largely exploited, ${ }^{15}$ underregulated, undervalued, ${ }^{16}$ as well as a sector whose enforcement and monitoring systems are at the weakest level, or simply not practicable, given their occupational dynamics. It is sui generis, and needs to be treated as such.

Their generally extraordinarily long hours of work largely earns them an economic consideration which is largely disproportionate to their responsibilities, and very seldom are necessary steps taken to commit employers to statutory-regulated wage standards, even in a rare moment where complaints are made. ${ }^{17}$ Whisson and Weil ${ }^{18}$ noted that live-in domestic workers are on duty for as long as they are awake. The common excuse amongst employers with regard to non-compliance with regulated wage standards is affordability, leaving employees with no alternative but to terminate employment - the route which very few would wish to take. The lack of specialised monitoring systems, the lack of readily available tailormade access to complaint mechanisms, ${ }^{19}$ and the ineffective popularisation of information regarding rights and remedies compound the status quo. Indeed, rights which are unknown cannot be exercisable and are effectively not rights.

Asked about the occupational challenges and benefits they (domestic workers) enjoy since the inception of the democracy in South Africa, this is what some of them had to say -

- "That, things are actually worse than before ... instead they denied any knowledge of the new laws.'

- "The boss can also tell you what to do around the house. For example, she'll say wash the dogs even though it's not your job to do that. Then she'll tell me to put sunscreen on the dogs because they get burnt. Now the dogs run away from me when they see me because they hate sunscreen. Have you ever seen a dog that uses sunscreen?" (Domestic Worker from Pimville, working in a Johannesburg suburb.) ${ }^{2}$

- 'Gertrude Skhosana who had a 24 years' service with her employer, survived four robberies at gun point and her hands tied on her back in her

13 Sharpless Cooking in Other Women's Kitchen: Domestic Sector in the South 1865-1960 (2010) 2; and see also May Unprotected Labour: Household Workers, Politics and Middleclass Reform in New York 1870-1940 20.

14 May Unprotected Labour: Household Workers, Politics and Middle-class Reform in New York 1870-1940 20.

15 Scaria Maid in Hell: Real Life Accounts of the Atrocities Faced by House Maids (2004) 31 . Du Toit "Situating Domestic Work in a Changing Global Labour Market" in Du Toit et al (eds) Exploited, Undervalued- and Essential: Domestic Workers and the Realisation of their Rights (2013) 2; and see also The Domestic Workers Convention: Turning New Global Labor Standards into Change on the Ground 6 (see fn 7 above).

16 See the Preamble of Convention 189.

17 See fn 2 above.

18 Domestic Servants: A Microcosm of the Race Problem 12.

19 Human Rights Watch research in $\mathrm{fn} 7$ above.

20 Ally From Servants to Workers: South African Domestic Workers and the Democratic State 9.

21 http://www.sacsis.org.za/site/article/473.1. 
madam's house. As a result of that, Madam called her names and dismissed her, accusing her of having a hand in the robberies, but the charges were later dropped. She went to the CCMA, but Madam did not show up. Until today she is not paid even a cent; instead the employer offered to compensate 24 years' service for only R5000.00.

- "On the other hand, Rose explains how she was raped by her employer. She says, one morning in 2000, the husband took his wife to work, returned home and walked around naked. He called me into his room and asked me to play with him. I was scared. I didn't know what to do, so I did it. According to Rose, the rapes continued. Since then 'When I heard him call my name, I knew why he was calling me. I decided to tell his wife the truth. She screamed that her husband would never sleep with a black woman and pushed me out the door.'

Against this background and at the heart of South African labour law lie longstanding common-law principles, amongst others, fair dealing between an employer and employee (employees' protection against unfair labour practices), the employer's duty to ensure safety and healthy work environment, to name just a few, which are also captured in the provisions of the Constitution, ${ }^{24}$ parallel international law instruments given effect to by some of the labour law legislation, as shall be seen in the discussion that follows. It is argued that domestic workers are not adequately protected in terms of statutes, and that their uniqueness requires special regulation and specialised control mechanisms which would be in line with the provisions of Convention $189 .{ }^{25}$ It is submitted that any form of protection that fails to take into account the guiding principles outlined in the Convention 189 regarding the unique nature of domestic sector, may well be regarded as a futile exercise. The dynamics of this sector should be appreciated. A one-size-fitsall approach, as reflected in the existing labour law, is "folly". Domestic workers are generally, illiterate, desperate, under-resourced, vulnerable and persons in need of special attention; therefore measures designed to address issues of domestic workers must take those inherent characteristics into account.

It is submitted also that laws alone, no matter how well drafted they may be, may not effect the necessary change to better the welfare of the people in this sector; instead, transformed hearts, souls and the way one thinks about people in the domestic sector will be appropriate. Hepple ${ }^{26}$ noted that simple "command and control" by means of the law cannot alone change human behaviour. In line with this, it is argued that an infusion into the law of

http://www.iol.co.za/news/crime-courts/fired-domestic-worker-fights-back-1.1650879.

$23 \mathrm{http}: / / \mathrm{www}$.iol.co.za/news/south-africa/domestic-worker-s-shocking-sex-slave-claims-1.2371 34\#.Vkxty03oupo.

24 Constitution of the Republic of South Africa, 1996.

25 Convention 189 provides that legislatures should take due consideration of the occupational nature of the domestic sector in order to ensure proper regulation. Article 18 of the same Convention urges member states to extend, or adapt existing measures to cover domestic workers, or to develop special measures.

26 "Negotiating Social Change in the Shadow of the Law" 2012 SALJ 129(2) 254. 
the value dosages such as $u b u n t u,{ }^{27}$ and the humaneness vision aspired by the legends like Biko ${ }^{28}$ as guiding principles may be helpful.

Expounding on the meaning of ubuntu Langa $\mathrm{J}$ in $S v$ Makwanyane ${ }^{29}$ said the following:

"The concept of ubuntu is of some relevance to the values we need to uphold. It is a culture, which places emphasis on communality and on the interdependence of the members of a community. It recognises a person's status as a human being, entitled to unconditional respect, dignity, value and acceptance from the members of the community [that] such person happens to be part of. It also entails the converse, however. The person has a corresponding duty to give the same respect, dignity, value and acceptance to each member of that community. More importantly, it regulates the exercise of rights by the emphasis it lays on sharing and co-responsibility and the mutual enjoyment of rights by all".

Moseneke DCJ remarked that, "it is indeed highly desirable and in fact necessary to infuse the law with ... the constitutional values, including ubuntu which inspire much of our constitutional compact ... Ubuntu carries in it ideas of humaneness, social justice and fairness ..."30

Mahomed $\mathrm{J}$ expressed his views in the following way -

"the need for ubuntu expresses the ethos of an instinctive capacity for and enjoyment of love towards our fellow men and women; the joy and the fulfilment involved in recognizing their innate humanity; the reciprocity this generates in interaction within the collective community; richness of the creative emotions which it engenders and the moral energies which it releases both in the givers and the society which they serve and are served".

\section{WHO IS A DOMESTIC WORKER AND WHAT SHE OR HE DOES}

A cursory definition of a domestic worker is someone who does household duties for another for a living. This simply means, persons (men and women) doing home jobs, that is, cleaning, cooking, taking care of the old, children, drivers, gardeners, etcetera. ${ }^{32}$ Hondagneu-Sotelo, ${ }^{33}$ defines domestic worker as somebody who does two (or more) jobs for the price of one, for example,

27 This a Zulu word which means "humaneness", "humanity" or "personhood". See $S v$ Makwanyane 1995 (3) SA 391 (CC) par 308; and Bennett "Ubuntu: An African Equity" 2011 14(4) PER 351.

28 In his book (I write what I like (2004) Biko warned us that the greatest gift we can give to one another is a humane face (51 and 108)).

29 Supra par 224; see Afriforum v Malema (2011) 6 SA 240 (EqC) par 19; and see also Rautenbach and Malherbe Constitutional Law (2004) 10.

30 Everfresh Market Virginia (Pty) Ltd v Shoprite (Pty) Ltd 2012 (1) SA 256 (CC) par 71; and see also $S$ v Makwanyane supra par 237.

31 Makwanyane supra par 264, 225 and 308.

32 Effective Protection for domestic workers: A guide to designing labour laws (International Labour Organization (2012)) 1; see ILO Report of the Committee on Domestic Workers, Provisional Record No 12 International Labour Conference, $99^{\text {th }}$ Session, Geneva 2010 par 204-211; and see also Lutz The New Maids: Transnational Women and the Care Economy (2011) 32.

33 Domestica Immigrant Workers Cleaning \& Caring in the Shadows of Affluence (2001) 5. 
nanny and housekeeper. Scaria ${ }^{34}$ describes domestic workers as "part of the forgotten mass of unorganised workers ... considered as 'personal property' to be used at employers' whims and fancies". ${ }^{35}$ In other circles paid domestic work is not seen as an economic activity, as it is believed that the responsibilities attached to domestic work are extensions of women's natural roles. ${ }^{36}$ However, according to Togrul, ${ }^{37}$ paid labour "without distinction" constitutes an economic activity; therefore domestic work is an economic activity. The ILO Convention $189^{38}$ provides that domestic workers like all other workers have rights and should therefore be treated with dignity. It defines "domestic worker" in the following terms -

"(b) the term domestic worker means any person engaged in domestic work within an employment relationship;

(c) a person who performs domestic work only occasionally or sporadically and not on an occupational basis is not a domestic worker."

As shall be clearer later some countries, including South Africa, took heed of Convention 189 to make provisions for domestic workers. For now it suffices to say that South Africa responded by creating additions to the Basic Conditions of Employment Act ${ }^{40}$ (BCEA) of Sectoral determination, ${ }^{41}$ which to a certain extent regulates issues in relation to domestic workers. In terms of this determination, "domestic worker" means -

"any domestic worker or independent contractor who performs domestic work in a private household and who receives, or is entitled to receive, pay and includes -

(a) a gardener;

(b) a person employed by a house hold as a driver of a motor vehicle; and

(c) a person who takes care of children, the aged, the sick, the frail or the disabled;

(d) domestic workers employed or supplied by employment services.

As evident from the definitions above, domestic work is virtually done at a employer's home. This form of occupation binds and isolates the domestic worker in the employer's home with no colleagues to talk to, but only the employer which very seldom is easy if not impossible at all to converse with due to either language barriers, power dynamics between the two, or lack of time due to the demanding nature of domestic work. It is submitted that a collection of the above features, characterising domestic work provide a breeding ground for mistreatment and abuse of domestic workers because the abuse happens privately, where there is hardly a witness to testify in the

\footnotetext{
Scaria Maid in Hell: Real Life Accounts of the Atrocities Faced by House Maids (2004) 42.

36 Hondagneu-Sotelo Domestica Immigrant Workers Cleaning \& Caring in the Shadows of Affluence 3; and see also Domestic Workers Count too: Implementing Protections for Domestic Workers 15 (fn 4 above).

37 Togrul "Linking Vulnerability to Poverty and Domestic Labor: A Case Study in Turkey" 1 www.policyinnovations.org/...labor.../poverty\%20domestic\%20labor\%2... . See also Lutz The New Maids: Transnational Women and the Care Economy.

38 The Domestic Workers' Convention, 2011 and Recommendation NO 201.

39 Article 1.

4075 of 1997. Similar definition is also found in $s 1$ of the Unemployment Insurance Contribution Act 4 of 2002.

41 Sectoral Determination: Domestic workers.
} 
domestic worker's favour in the event that the abuse is reported. For the same reason, domestic workers feel discouraged to report their misery and abuse as courts or other fora require witnesses to prove cases. This may well explain why our courts are yet to deal with domestic workers' abuses despite the number of abuse cases we hear of in media, both print and electronic.

Amid all these challenges in the domestic sector, South Africa has been receiving praises the world over for having taken the front seat in acknowledging and elevating the status of the household workers, and also extending to them legal protection as employees. ${ }^{42}$ It is argued that as many entertain such positive thoughts, we should also be so bold as to test the impact this much-celebrated protection has had on the beneficiaries, and the extent and enforceability thereof. As was stated by one author:

"writing law ... is one thing ... abiding by it and ensuring it is policed is another".

The discussion below will scrutinize the available protection measures and their effect in South Africa in as far as these are applicable to domestic workers.

\section{THE LEGISLATIVE FRAMEWORK IN SOUTH AFRICA}

\section{The Constitution ${ }^{44}$}

The Constitution is not only the supreme law of the land against which all laws should be gauged for validity; ${ }^{45}$ it also makes a provision for the right of every employee to a fair labour practice ${ }^{46}$ and the right to environment that is not harmful to one's health or well-being. ${ }^{47}$ Section 9 provides for the right of everyone to equal protection and benefit of the law ${ }^{48}$ and not to be treated inhumanely. ${ }^{49}$ There is no express mention of the word "domestic worker" in the Constitution, and neither does the Constitution define "domestic worker". However, it should be accepted that the provisions of the Constitution are so

42 South Africa is among the first countries in the world (namely) to ratify Convention 189 and the first in Africa. See also fn 40 and 41 above.

43 Newspaper article by Mandy de Waal entitled "Still on the Fringes: Domestic Worker see No Light" http://www.dailymaverick.co.za/article/2012-06-05-still-on-the-fringes-domestic-worker s-see-no-light/.

44 The Constitution of the Republic of South Africa, 1996.

45 S 2 provides that (a) the Constitution supreme law of the Republic; and (b) obligations imposed by it must be fulfilled.

46 S 23 of the Constitution provides that every worker has the right

- to fair labour practices;

- to form and join a trade union;

- to participate in the activities and programmes of a trade union,

- and to strike.

47 S 24 of the Bill of Rights.

48 S 9(1)

49 S 12. 
generously constructed that they also apply to domestic workers and their workplaces. Section 9, 12 and 23 of the Constitution apply without distinction to all employees.

\section{The Labour Relations Act 66 of 1995 (the LRA)}

Similarly, the LRA does not define "domestic worker" but the closest it came to saying something closely linked to "domestic worker" is the restrictions of labour rights it places on the domestic sector. ${ }^{50}$ Despite legislative silence, it would seem that domestic workers are also covered by some of the provisions of the Act by virtue of the fact that they qualify as employees, although, as often said, non-standard ones. ${ }^{51}$ The extent and applicability of the protection provided by the Act towards domestic workers registered little impact, if not anything at all, as the drafters of the Act failed to take into account the occupational uniqueness of this sector.

Section 4 of the LRA provides for every worker the right to form, join and to participate in the activities and programmes of the trade union for bargaining purposes. Whisson and Weil looked at the difficulties of organising workers employed individually. They noted that domestic workers are not well placed to create an active and effective trade union to fight for their interests on a collective basis. Equally there are no employers' organisations with which to bargain. ${ }^{52}$ In addition to this, Ally ${ }^{53}$ notes that it is a Herculean task to organise domestic workers effectively. ${ }^{54}$ She, just like Whisson and Weil, attributes the difficulty of organising domestic workers "according to" uniqueness of their occupation. She also held that their isolation, dependence [on the employer] and invisibility well define the implausibility of public politics among domestic workers in South Africa. ${ }^{55}$

It is also commonplace that trade unions generally sustain themselves through membership subscriptions. With that said, it is submitted that the feasibility of drawing subscriptions from a structurally hand-to-mouth salary framework of the domestic workers may well be tantamount to taking the whole bread away from a domestic worker's table. The prematured demise

50 S 17 reads, "(1) for the purposes of this section, "domestic sector" means the employment of employees engaged in domestic work in their employer's homes, or on the property on which the home is situated. (2) The rights conferred on representative trade unions by this Part in so far as they apply to the domestic sector are subject to the following limitations -

(a) the right of access to the premises of the employer conferred by section 12 on an office bearer or official of a representative trade union does not include the right to enter the home of the employer, unless the employer agrees; and

(b) the right to the disclosure of information conferred by section 16 does not apply to domestic sector."

51 Du Toit in Du Toit et al Exploited, Undervalued- and Essential: Domestic Workers and the Realisation of their Rights (2013) 2.

52 Whisson and Weil Domestic Servants: A Microcosm of the Race Problem 52.

53 Ally From Servants to Workers: South African Domestic Workers and the Democratic State.

54150.

55 148. See also Du Toit and Tiement "Do Cooperatives Offer a Basic for Worker Organisation in the Domestic Sector? An Exploratory Study" 201536 ILJ 1679. 
of the South Africa Domestic Service and Allied Workers Union ${ }^{56}$ (SADSAWU) provides a classic example.

The South African Domestic Workers Union (SADWU) was established in 1984 , but it succumbed due to financial constraints. SADWU could not sustain itself solely on members' subscriptions; therefore, there was a need for external funding which has still not been forthcoming. It received funding, although for a shorter period, from the Netherlands to organise conferences for domestic workers. ${ }^{57}$ In 2000 SADSAWU was launched in KZN to mobilize, educate and ensure the improvement of domestic workers' lives is realized, but with a shoestring budget. It struggled to agitate for or propagate its course satisfactorily.

Notwithstanding the reality of being underresourced, SADSAWU played an important role in the processes leading up to the adoption of the ILO Convention on domestic workers. It is quoted as saying the following:

"it is now recognised internationally that 'Domestic Work is Work' and 'Domestic Workers are Workers' but we know, from our experience of organising and representing domestic workers in South Africa, that what is on paper does not always represent what is on the ground. The majority of domestic workers in our country is not organised, do not have contracts and have no say in the wages they receive and the conditions under which they work - they are far removed from the institutions that have been set up to protect their rights and they remain at the mercy of their employers. The mentality in our country when it comes to domestic workers is still that of 'baasskap'. The domestic worker is not supposed to be thinking of rights and decent work; the domestic worker must only think of how grateful she is to have a job and must always please her employer. We have a long way to go to change this mentality and bring about respect for domestic workers and the work they do. Too often are domestic workers treated badly and sometimes dismissed because their employer is simply having a bad day."

\section{The Basic Conditions of Employment Act 75 of 1997 (BCEA)}

At least, domestic workers receive for the first time an express legislative provision under the BCEA. ${ }^{58}$ Not only does the BCEA refer to "domestic worker", it also defines and regulates the domestic sector as an occupation. "Domestic worker" is defined in the following terms:

"'domestic worker" means an employee who performs domestic work in the home of his or her employer and includes -

(a) a gardener;

(b) a person employed by a household as driver of a motor vehicle; and

56 Then as South African Domestic Workers Union (SADWU). See the history of SADSAWU http://www.idwfed.org/en/affiliates/africa-1/south-africa-domestic-service-and-allied-workersunion-sadsawu.

57 Du Toit "Extending the Frontiers of Employment Regulation: The Case of Domestic Employment in South Africa" 201014 Law, Democracy \& Development 209; see Nyman "The Death of SADWU: The Birth of a New Organisation?" 199721 South African Labour Bulletin 34; and see also Du Toit et al (eds) Exploited, Undervalued- and Essential: Domestic Workers and the Realisation of their Rights 290.

58 Sectoral determination 7 . 
(c) a person who takes care of children, the aged, the sick, the frail or the disabled, but does not include a farm worker;"

The BCEA also provides a list of rights and entitlement to which almost all employees, such as domestic workers included, are entitled. The BCEA furthermore, made provisions in terms of the Sectorial Determination $7^{59}$ which, it is submitted, have proved inadequate in bettering the lives of the people in this sector, and may very well be regarded as a paper-protection without practical sense unless adapted to meet special needs and circumstances of domestic workers, as set out in terms of Convention 189. South Africa is a signatory to this Convention and by virtue of which made an undertaking to conform, but it lacks the will to act accordingly. As stated elsewhere, written law is one thing, but abiding by it and ensuring it is policed is another. Article 21 of Convention 189 makes mention of a series of policy control measures that may be of great assistance and beneficial to domestic workers if adopted, namely, a telephone hotline, preplacement inspections of households, and emergency housing, but none of these is covered in the BCEA, or alternatively, sectoral determination.

\section{Unemployment Insurance Contributions Act 4 of 2002 (the UICA) and Unemployment Insurance Act 63 of 2001 (the UIA)}

These Acts place the responsibility on the employer of a domestic worker who works more than 24 hours per month for such an employer, necessary to register for Unemployment Insurance Fund with the department of labour. ${ }^{60}$ The UICA requires of the employer and employee to contribute one per cent of the employee's monthly remuneration, or any pay intervals according to which such an employee is paid. ${ }^{61}$ The same is deposited with the Commissioner of the Fund, ${ }^{62}$ failing which, the employer will be liable. ${ }^{63}$ However, very few are registered. ${ }^{64}$ This may be attributable to a range of factors, such as less distribution of information to consumers, and ignorance of the rule of law by employers who are largely literate and probably aware of the need to register, but deliberately avoiding registration, because that would entail their attaching the necessary employment contract, which spells out all the terms and conditions of employment as required by the Act. They are basically scared of being exposed and are effectively not traceable until they are registered.

\footnotetext{
See Government Notice NO. 38254.

60 S 56 read with regulation 8 of the Unemployment Insurance Act and S 10 of the Unemployment Insurance Contribution Act 4 of 2003.

61 S 6 of the UICA.

S 7 of the UICA.

313 of the UICA.

64 See fn 6 above. See also Domestic Worker: From Modern-day Slavery to Equal Right (a policy briefing compiled by an organisation called SOLIDAR) www.solidar.org/IMG/ pdf/h_solidar_briefing_domestic_workers.pdf 6 . In terms of this policy briefing document disregard rules regulating of the domestic sector is not a problem in South Africa only, but Ghana and more other countries have the same problem.
} 


\section{Occupational Health and Safety Act 85 of 1993 (the OHSA)}

It is no secret that safety and health of every employee are fundamental human rights ${ }^{65}$ and that workplace laws worldwide place the duty on the employers to maintain safety and a healthy workplace environment. South Africa is not an exception. ${ }^{66}$ Occupational safety and health include the latter regarding domestic workers. In fact, it is should be accepted that, given the nature of their work domestic workers are most deserving people to experience a safe and healthy workplace, as their daily work exposes them to health hazardous objects, or high viral loaded areas like, for example, toilets, handling and inhaling toxic cleaning chemicals, use of electrical appliances, knives and such like. The ILO Convention 189 takes the issue of domestic workers' safety and health further by urging member states to take effective measures with due regard to the specific characteristics of domestic work. ${ }^{67}$ At least South Africa passed two Acts, namely the Occupational Health and Safety Act $^{68}$ (the OHSA), which apply to all workplaces and the Mines Health and Safety Act ${ }^{69}$ (the MHSA), which safeguards South African workforce at mines. However, for the purpose of the current discussion the OHSA only is relevant, and whether or not employers in the domestic sector are complying with this requirement remains a statistical question, but the fact that South African Courts are yet to hear cases on this aspect should be of great concern to all South Africans.

\section{Compensation for Occupational Injuries and Diseases Act 130 of 1993 (the COIDA)}

Occupational injuries and illness remain part and parcel of every workplace environment and for employees. For as long as they work, they are prone to injuries or illness. In line with Article 13 of Convention 189, the COIDA provides for compensation for disablement caused by occupational injuries or diseases sustained or contracted by employees in the course of their employment, or for death resulting from such injuries or diseases. COIDA provides a list of persons or employees it covers. In terms of this Act an "employee" means a person who has entered into, or works under a contract of service, or of apprenticeship, or learnership with an employer, whether the contract is express or implied, oral or in writing, and whether the remuneration is calculated by time or by work done, or is in cash or in kind, and ... excludes a domestic employee employed as such in a private household ... ${ }^{70}$ This exclusion from the COIDA effectively means that

\footnotetext{
S 24 of the Constitution.

Article 7 of the International Covenant on Economic, Social and Cultural Rights, 1996. See also Hilgert "The Future of Workplace Health and Safety as a Fundamental Human Right" 201334 Comparative Labour Law \& Policy Journal 720.

67 Article 13

6885 of 1993.

6929 of 1996.

$70 \mathrm{~S} 1(\mathrm{xix})(\mathrm{d})(\mathrm{v})$.
} 
domestic workers do not have any remedy except expensive and burdensome civil processes - a challenge which makes domestic workers even more vulnerable. In line with this, the Minister of Labour, Ms Mildred Oliphant, announced in 2014 that this Act will soon cover domestic workers. ${ }^{31}$ Needless to say this, to this day, domestic workers are not covered.

\section{ENFORCEMENT MEASURES}

In addition to setting out protections for domestic workers and to complete the process of ensuring decent work for them, an effective compliance system is necessary. In fact, compliance issues should be considered as part and parcel of designing laws and regulations for protecting domestic workers' rights. South Africa makes use of labour inspectors to ensure compliance with labour laws. A serious concern regarding labour inspectors is that their approaches are more reactionary and thus not suitable for underprivileged people with no knowledge of the law and therefore unlikely to report firstly, what they do not know and secondly, to the institution whose existence or whereabouts of which they are not aware. While Convention 189 provides for access of domestic workers to court processes, tribunals and other disputes-settlement mechanisms, Recommendation No. 201 proposes distribution of this information to the beneficiaries, raising of awareness regarding applicable laws and the obligations arising from them, as well as the provision of assistance to domestic workers, seeking to enforce their rights. Article 21 of Convention 189 mentions a series of tools that the State should implement for domestic workers, such as a telephone hotline, preplacement inspections of households, and emergency housing. But South Africa provides none of those things. In line with this recommendation, at least Kenya has gone all out to establish a specific centre namely, Centre for Domestic Training and Development, (the CDTD) that provide training to domestic workers on issues relating to labour and their human rights. ${ }^{2}$ In addition to that, the Kenyan Court has had an opportunity to successfully hear a case regarding a domestic worker. ${ }^{73}$

\section{CONCLUSION}

Indeed, form should not be confused with substance. The protection of domestic workers will remain a pipe dream for as long as their occupational uniqueness were not taken into account during policy-making. The journey

71 http://www.sanews.gov.za/south-africa/act-be-extended-cover-domestic-workers.

72 https://kituochasheria.wordpress.com/2015/10/06/access-to-justice-for-kenyan-domesticworkers/.

73 Justice Monica Wanjiru Mbaru awarded Robai Musinzi, a house help, a total of Sh175, 533 for wrongful dismissal by her employer, Safdar Mohamed Khan, despite the fact that there was no written agreement to support the claim. Mr Khan had hired Mrs Musinzi to work at his Lavington home in Nairobi through a verbal agreement promising to pay her Sh11, 000 per month. A disagreement between the two led to Mr Khan summarily dismissing the domestic worker after 50 months of service, sparking a year-long legal battle that ended with the court granting all Mrs Musinzi's prayers and handing domestic workers a resounding victory against their employers http://www.businessdailyafrica.com/Domesticworkers-win-major-pay-victory-against-employers-/-/539546/1762276/-/4rapci/-/index.html. 
to integrate domestic workers into the mainstream-democratic processes must begin with our changing attitudes about domestic work and seeing what domestic labour as an occupation just as in the case of any other, for example, mining, nursing, and so forth, with its own challenges and dynamics. Verily, occupations differ and so are the ways to regulate them. Regulating mining houses may be way different from regulating the health profession. Each has its own dynamics that inform policy make-up. Until the current situation of the domestic worker is rationally and clearly acknowledged, the assertion that domestic workers are protected, remains abstract and nominal. The one-size-fits-all approach is failing the domestic worker. ${ }^{74}$

${ }^{74}$ See fn 55 above. 